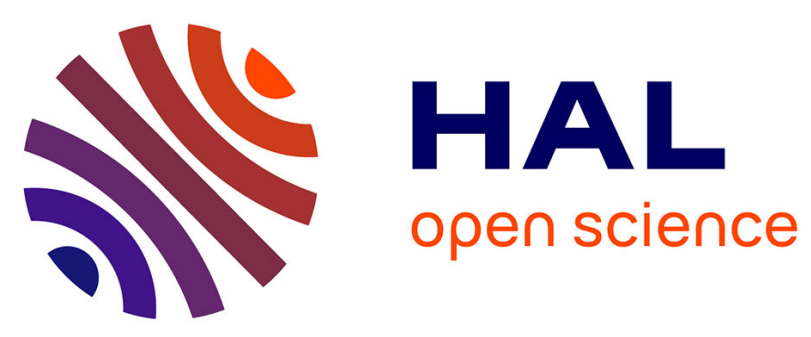

\title{
Sex reversal in vertebrates
}

Eric Pailhoux

\section{To cite this version:}

Eric Pailhoux. Sex reversal in vertebrates. Karger, 10 (5-6) Special Issue, 129 p., 2016, Sexual Development, 978-3-318-06010-2. 10.1159/isbn.978-3-318-06011-9 . hal-02793399

\section{HAL Id: hal-02793399 https://hal.inrae.fr/hal-02793399}

Submitted on 5 Jun 2020

HAL is a multi-disciplinary open access archive for the deposit and dissemination of scientific research documents, whether they are published or not. The documents may come from teaching and research institutions in France or abroad, or from public or private research centers.
L'archive ouverte pluridisciplinaire HAL, est destinée au dépôt et à la diffusion de documents scientifiques de niveau recherche, publiés ou non, émanant des établissements d'enseignement et de recherche français ou étrangers, des laboratoires publics ou privés. 


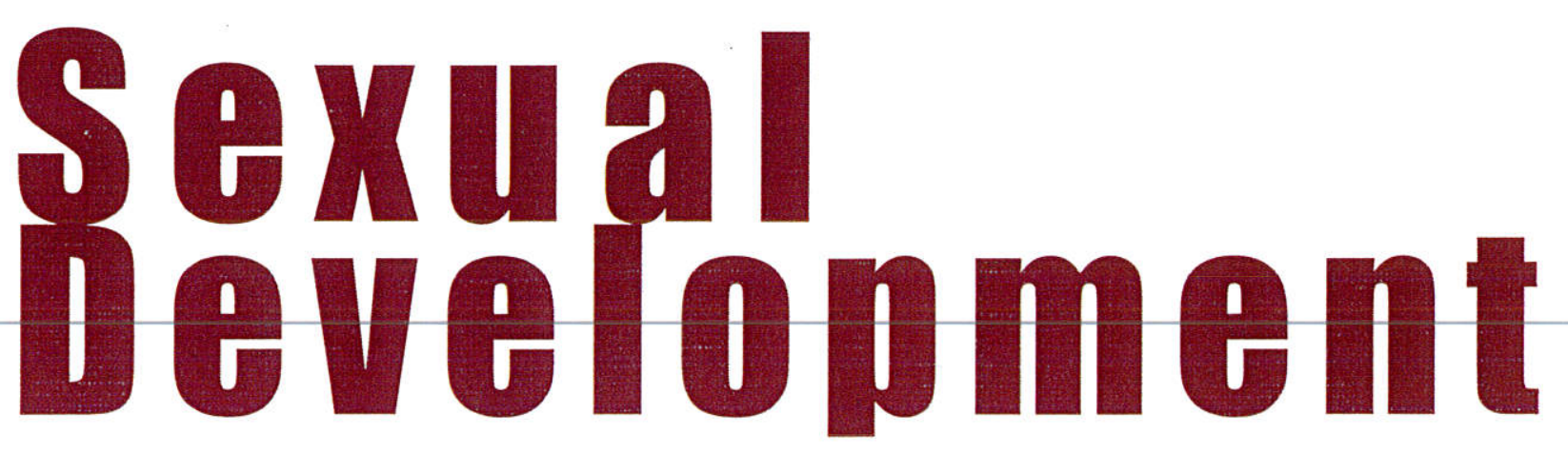

\section{Sex Reversal in Vertebrates}

Editor

Eric Pailhoux, Jouy-en-Josas

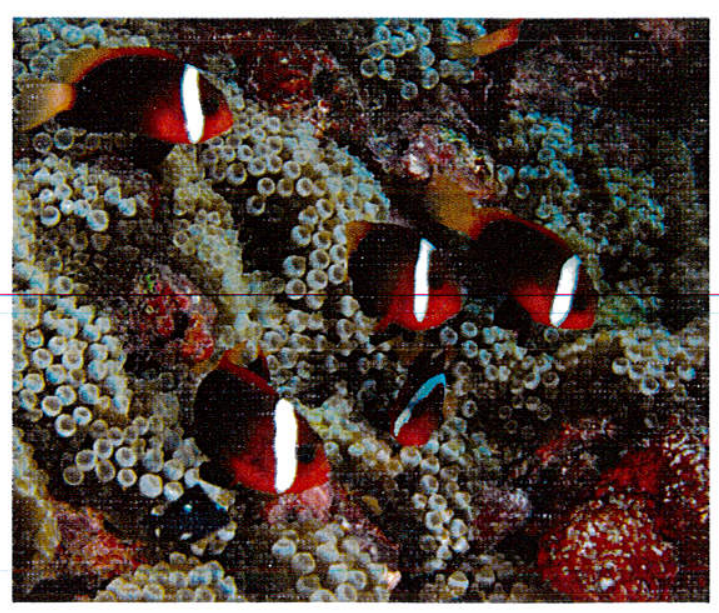

